\title{
TREND ANALYSIS OF THE ROCK MASS PROPERTIES ON THE BASIS OF FRACTAL REPRESENTATION OF SPATIAL RANGES
}

\author{
Oleg Georgievich Latyshev, \\ gtf.shs@ursmu.ru \\ Ol'ga Olegovna Kazak \\ dozlat1@rambler.ru
}

\author{
Ural State Mining University \\ Ekaterinburg, Russia
}

Evaluation of rock mass characteristics is the basis for designing the technology of mineral deposits development, which indicates the relevance of the work.

The purpose of the present work is to establish the laws of spatial distribution of rock mass properties. Their establishment requires the solution of the following problems: determination of the probability of a trend; identification and elimination of emissions (local component) and construction of a trend line.

The research methodology consists of using the tools of fractal geometry to determine the properties of a random spatial series. The use of the apparatus of classical trend analysis, based on purely statistical analysis, in relation to the specifics of research data does not provide an adequate solution to these problems. This paper discusses the results of implementing the fractal representation of the spatial series in case of the rock mass strength distribution in the Yubileynoye deposit (Bashkortostan). The quantitative estimation of the trend line as a fractal object is to determine its fractal dimension by the method of "fractal lengths". Step-by-step implementation of this method allowed identifying areas of the rock mass with natural variability of properties by depth. The variation of the values of a number (the random component) obeys an equation of the fractal Brownian motion (FBM). Determination of the parameters of this equation makes it possible to predict the characteristics of the rock mass in those areas where engineering-geological testing was not carried out. For this purpose, a statistical model of variability of the characteristics of the array, based on the Monte Carlo method was developed. Implementation of the model allows us to add the spatial series (replicate sample), i.e., to predict the properties of the array between the points of sampling.

Summary. The proposed techniques and software that forms the methodology of fractal analysis of variability of a rock mass at depth and along strike of the deposit. The methodology provides additional information for engineering and geological studies of deposits, especially with a limited amount of sample data. It allows increasing the reliability of the forecast of mining conditions for the construction of mines and mining operations.

Keywords: rocks; rock mass strength; fractal trend analysis.

ntroduction

The technology of mineral deposits development is largely determined by the properties of rocks, which compose the rock mass. One of the most important goals of engineering-geological substantiation of design solutions is the prediction of variability of rock properties along the stretch and depth of the deposit. This forecast is based on trend analysis. The classical trend analysis solves the following problems [1]: assessment of the presence of regularity in the variability of the parameters studied; identification and elimination of the local component of the series; establishment of the trend line; determination of its natural and random component. The solution of these problems with the help of the correlation analysis does not provide a reliable picture of the trend due to the natural variability of the array, which causes the presence of values that do not fit into the framework of the accepted statistical function of the distribution of "popping up" meanings. Classical methods of estimation of such local values using Bayesian regression analysis [1] or Hoeke-Brown criterion [2] are overly formalized. They do not take into account the geological history of rock formation. Trend analysis based on the classification of rocks by properties [3] is a too rough approximation. This analysis does not provide a high-quality design of mining technology. Consideration of the spatial trend of rock strength from fractal positions provides additional opportunities.

Results

Let us consider the possibility of trend analysis on the example of the variability of rock strength by the depth of the Yubileynoye deposit (Bashkortostan). Strength characteristics of rocks were determined by means of the laboratory studies of cores extracted from exploratory wells. To assess the rock mass strength, corrections for rock pressure, humidity, scale effect and fractured rock mass structure were introduced to the laboratory data [5-7]. Fig. 1 shows the spatial range of the strength of the rock mass variability based on depth.

The appropriate computer software was developed for the classical trend analysis procedure. The first goal is to assess the probability of a trend. The analysis of quite numerous methods of solving this problem [5] showed that the Wald criterion [1,8] was the most informative and reliable for spatial series of variability of rock properties. To test the hypothesis about the existence of a trend according to this criterion is determined by the number of crossings of the graph of the variability of the index in its median value. The computer program determines deviations from the median (" +1 " or " -1 ") and the number of intervals greater than the median $-n_{1}$ and less than the median $n_{2}$. The value of the criterion $Z$ is calculated based on the mathematical expectation and variance of deviations. The probability of trend absence is determined with the help of the normal distribution function. For the given series, this probability is 0.077 . Therefore, the probability of a trend $(P=0.923)$ is quite high.

Another goal is to determine the trend equation (line). Our experience in analyzing the spatial series of rock properties has shown that even higher order polynomials were not able to reliably describe the natural variability of rock properties. The use of 


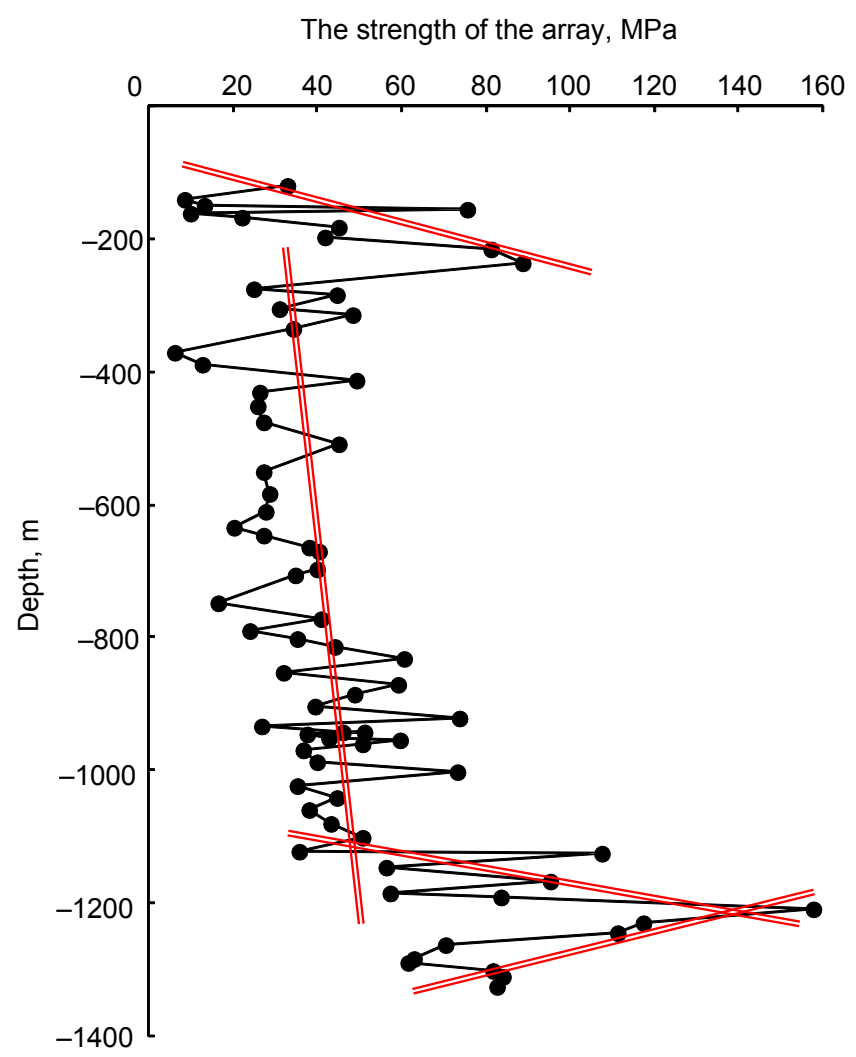

Figure 1. A chart of the strength of the rock mass according to the depth of the Yubileynoye deposit. Рисунок 1. Диаграмма прочности породного массива по глубине Юбилейного месторождения.

different methods of "alignment" is also associated with an unacceptable loss of information about the distribution of properties. Additional important information is given by considering spatial series from fractal positions.

If a spatial series has fractal properties, the dependence of its length $L(\delta)$ on the measurement step $\delta$ is subject to the power law (Richardson's law) [7, 8]:

$$
L(\delta) \sim \delta \varphi \text { at } \beta<0
$$

There are several ways to calculate the fractal dimension of a series. The method of fractal lengths is one of the most informative and amenable to computer formalization $[9,10]$. It determines the procedure for calculating $L(\delta)$. In this case, the whole series, consisting of Ni members, is divided into intervals of $[i \delta-(i+1) \delta]$. Within each interval, the value of the $<Y(i \delta)>$ function is defined as the arithmetic mean of all points within that interval. The curve length at a given step $\delta$ is calculated as the sum of the function increments by the formula:

$$
L(\delta)=\sum_{i=1}^{N} \mid<Y(i \delta)>-<Y((i-1) \delta)>.
$$

The fractal dimension of the series is determined on the basis of linear approximation of the dependence (1) in double logarithmic coordinates. From this equation follows:

$$
\ln L(\delta)=\beta \ln \delta+\ln \alpha,
$$

where $\ln \alpha=$ const.

Here $\beta$ is the angular coefficient of the equation graph (3) associated with the fractal dimension of the series: $d_{f}=1-\beta$. Then, ignoring the constant, you can write $\log L \sim\left(1-d_{f}\right) \log \delta$. Thus, to determine the fractal dimension of the $d_{f}$ series, it is necessary to find the dependence of the length of the 1 series on the measurement step $\delta$. If in logarithmic coordinates this dependence turns out to be linear, then the series will be a fractal, i. e., it will have the property of self-similarity. The parameters of equation (3) will be determined by the method of "least squares".

For Fig. 2 the trajectories of the considered trend are shown at successive change of the measurement step. The results obtained (Fig. 3) are a good match with the linear dependence (3). The coefficient of reliability of approximation is $R^{2}=0.94$. Therefore, the considered series of variability of strength of the massif by the depth is a fractal object. Its total fractal dimension is $d_{f}=1.82$.

The obtained data refer to the entire strength chart. A step-by-step fractal trend analysis allowed identifying the intervals of depths with a steady pattern of strength changes. For the purposes of mining technology design it is sufficient to determine 


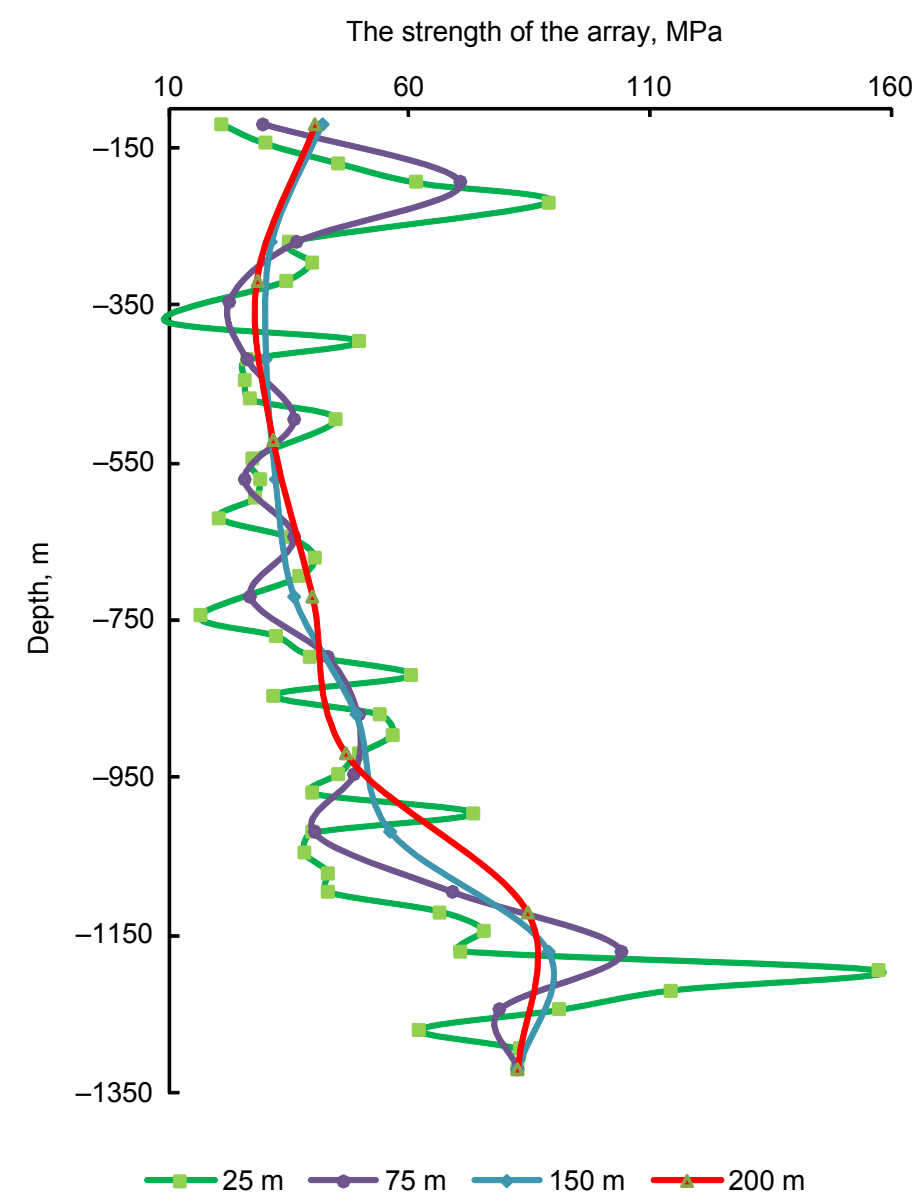

Figure 2. The trajectory of the trend line with different measurement step.

Рисунок 2. Изменение траектории линии тренда при различном шаге измерений.

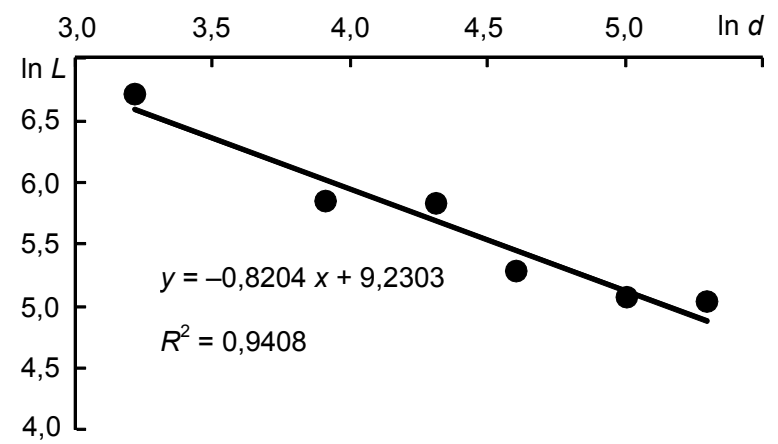

Parameters of the trend line of different depths.

Параметры линии тренда различных участков глубин.

\begin{tabular}{cccc}
\hline \multirow{2}{*}{ Depth intervals, $\mathrm{m}$} & \multicolumn{2}{c}{$\begin{array}{c}\text { Parameters of the equation } \\
\sigma_{\text {сж }}=k H+a\end{array}$} & $\begin{array}{c}\text { Correlation } \\
\text { coefficient }\end{array}$ \\
\cline { 2 - 3 } & \multicolumn{1}{c}{$k$} & $a, \mathrm{MPa}$ & \\
\hline $120-360$ & 0.58 & -59 & 0.692 \\
$360-1100$ & 0.02 & 20 & 0.453 \\
$1100-1200$ & 0.62 & -634 & 0.604 \\
$1200-1330$ & -0.61 & 868 & -0.758 \\
\hline
\end{tabular}

Figure 3. The graph of the trend equation (2).

Рисунок 3. График уравнения (2) тренда.

the tendency of strength change with depth in these areas, i. e. to use a linear equation of the form: $\sigma_{c K}=k H+a[11,12]$. The parameters of the equation in the selected areas are shown in the Table. These areas are marked with red lines in the Fig. 1.

While exploration drilling extraction of cores for testing rocks is extremely uneven. In particular, for the considered series testing intervals reached 30-50 meters in depth [5]. At these intervals, the strength values of the pattern remain unknown. In order to form a reliable trend of variability of rock mass strength in depth, such intervals should be filled in, i. e. to give a forecast of strength at these depth intervals. As shown earlier, the considered strength series is a fractal object, therefore, it has invariance to scale transformation (self-similarity) [13, 14]. Then for the solution of the specified problem it is necessary to use methods of fractal geometry.

In this case, the variability of rock strength can be described by the process of fractal Brownian motion [15]. Its implementation can serve as a method of the "middle displacement" [11]. The idea of this method is to calculate the random displacement of a point located in the middle of a line segment connecting the nodal points. Then, the mean displacement of the obtained data is determined $2,4,8, \ldots, 2^{(n+1) / 2}$ segments, where $n$ is the number of steps (iterations) required. With each modeling step, the length of the considered segments decreases, and in this regard, the median displacements $\Delta y$ should also decrease in proportion: 

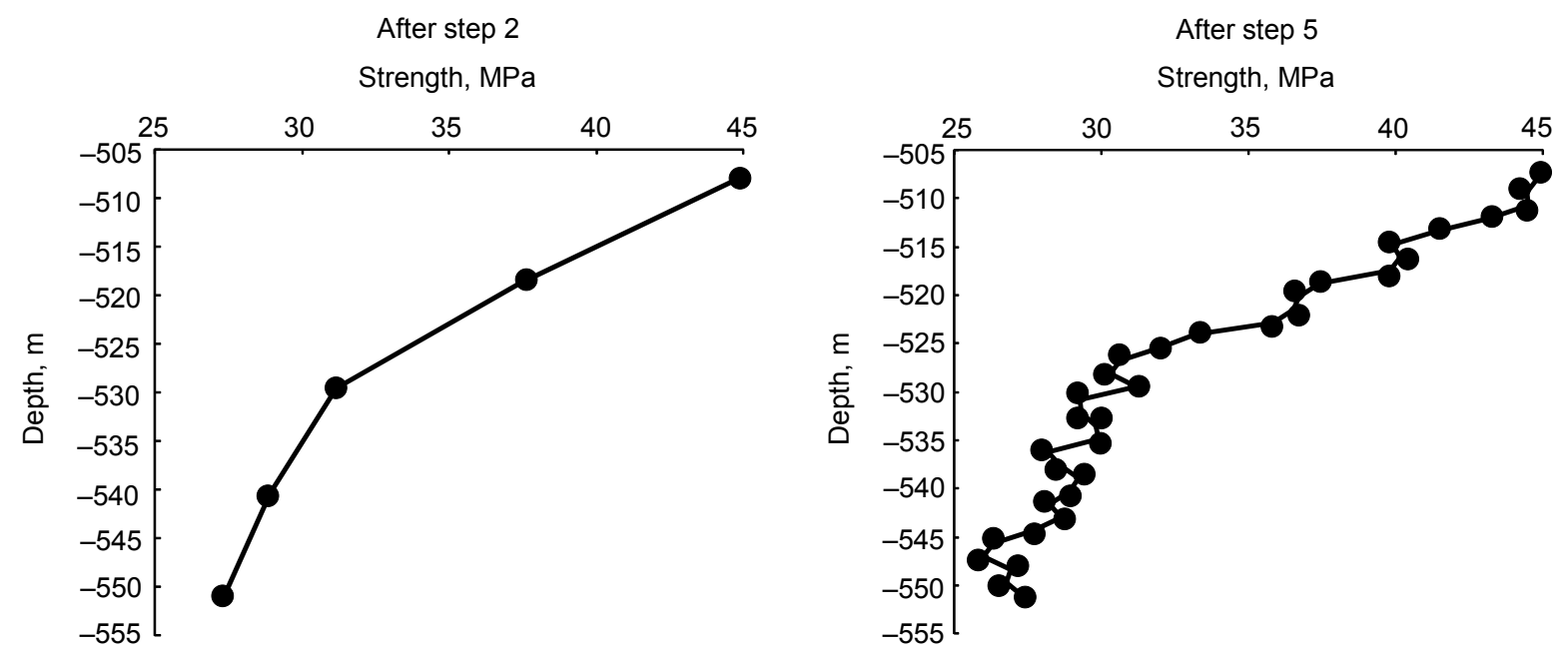

Figure 4. Implementation of the "mean displacements" method.

Рисунок 4. Реализация метода «срединных смещений».

$$
\begin{gathered}
\Delta y(t)=\frac{1}{2^{k H}} \sigma \sqrt{1-2^{2 H-2}} g . \\
t=k / 2^{n} \text { when } k=0,1, \ldots, 2^{n} .
\end{gathered}
$$

where $H$ is the index of the Gelder, $H=2-d_{j} g$ is the normally distributed random numbers generated by the computer program Microsoft Excel. The magnitude of the scale factor $\sigma$ is determined by the variance of the original series $S^{2}=770 \mathrm{MPa}^{2}$ :

$$
\sigma=\sqrt{\frac{S^{2}}{\left|t_{2}-t_{1}\right|^{2 H}}},
$$

where $\left|t_{2}-t_{1}\right|$ is a forecast step (distance between node points).

To implement this procedure, a statistical (simulation) model based on the Monte Carlo method was developed [18]. By averaging the multiple implementation of the model, the most probable points of the series are determined. Let us consider the implementation of the program on a specific example. In the depth interval of 508-551 meters there are no experienced points. Sequential replenishment (replication) of the sample in this interval is illustrated by graphs in Fig. 4.

The left graph shows the probabilistic strength values after two iterations of the model. After the fifth step, there is sufficient information about the probable strength of the array in a given depth interval. In principle, you can get a smooth curve of strength for any part of the array. At the same time, it should be noted that the zones of rock crushing, clearly fixed in exploration drilling, should be excluded from consideration.

The next goal of the analysis is to assess the reliability of the forecast, i.e. to determine the natural and random components of the trend. The variance of the trend's natural component is determined as the difference between the total variance $S_{0}^{2}$ and its random component $S_{\vec{n}}^{2}: S_{3}^{2}=S_{0}^{2}-S_{\vec{n}}^{2}$. For the series considered, the total variance as a measure of the variation in strength relative to the total average is $S_{0}^{2}=1972 \mathrm{MPa}^{2}$. The random variance is determined by the sum of squares of deviations of experimental values from trend lines in the selected areas (Fig. 1). The value of the random dispersion is $S_{\tilde{n}}^{2}=118 \mathrm{MPa}^{2}$. In this case a natural component of variance defined as the difference $S_{3}^{2}=1854 \mathrm{MPa}^{2}$. Therefore, it can be affirmed that the strength of rocks naturally varies with the depth of their occurrence. Indeed, the natural component in the total variance exceeds $94 \%$. The average coefficient of variation of experimental values from the trend line is $8.2 \%$.

Conclusion

Thus, fractal studies of spatial series allow predicting the measure of variability of rock properties expressed in their fractal dimension. They allow allocating depth intervals with different trends of property changes with depth. They also make it possible to replicate the sample by using a simulation model based on the method of "average displacement". All of this allows us to obtain additional information that increases the reliability of the design of mining processes.

\section{REFERENCES}

1. Latyshev O. G., Kazak O. O. 2013, Matematicheskiye metody $v$ gornom dele [Mathematical methods in mining]. Ekaterinburg, $146 \mathrm{p}$.

2. Contreras L. F., Edwin T., Brown M. 2018, Bayesian data analysis to quantify the uncertainty of intact rock strength. Journal of Rock Mechanics and Geotechnical Engineering, no. 10, pp. 11-31.

3. Hoek E., Brown E. T. 1997, Practical estimates of rock mass strength. International Journal of Rock Mechanics and Mining Sciences, no. 34 (8), pp. 1165-1186.

4. Miranda T., Sousa L. R., Gomes A. T., Tinoco J., C. Ferreira C. 2018, Geomechanical characterization of volcanic rocks using empirical systems and data mining techniques. Journal of Rock Mechanics and Geotechnical Engineering, no. 10, pp. 138-150.

5. Khani A., Baghbanan A., Norouzi S., Hashemolhosseini H. 2013, Effects of fracture geometry and stress on the strength of a fractured rock mass. International Journal of Rock Mechanics \& Mining Sciences, no. 60, pp. 345-352.

82 Латышев О. Г., Казак О. О. Тренд-анализ свойств породного массива на основе фрактального представления пространственных рядов // Известия УГГУ. 2018. Вып. 2(50). С. 79-84. DOI 10.21440/2307-2091-2018-2-79-84 
6. Latyshev O. G., Karasev K. A., Martyushov K. S. 2013, Fraktalnyy trend-analiz izmenchivosti vremennykh i prostranstvennykh ryadov svoystv gornykh porod i massivov [The fractal trend-variability analysis of the temporal and spatial series properties of rocks and arrays]. Izv. vuzov. Gornyi zhurnal [News of the Higher Institutions. Mining Journal], no. 2, pp. 73-79.

7. Martyushov K. S. 2013, Prognoz prochnosti porodnogo massiva [Prediction of strength of rock mass]. Izv. vuzov. Gornyi zhurnal [News of the Higher Institutions. Mining Journal], no. 1, pp. 44-47.

8. Kobzar' A. I. 2006, Prikladnaya matematicheskaya statistika: dlya inzhenerov i nauchnykh rabotnikov [Applied mathematical statistics: for engineers and scientists]. Moscow, $816 \mathrm{p}$.

9. Mandelbrot B. 2002, Fraktal'naya geometriya prirody: per. s nem. [Fractal geometry of nature: Translated from German]. Moscow, $656 \mathrm{p}$.

10. Feder E. 1991, Fraktaly: per. s angl. [Fractals: Translated from English]. Moscow, 262 p.

11. Krylov S. S., Bobkov N. Yu. 2004, Fraktaly v geofizike [Fractals in Geophysics]. Saint Petersburg, 138 p.

12. Kronover R. 2006, Fraktaly $i$ khaos $v$ dinamicheskikh sistemakh: per. $s$ angl. [Fractals and chaos in dynamic systems: Translated from English]. Moscow, $488 \mathrm{p}$.

13. 2007, Teoreticheskiye osnovy prognoza i upravleniya svoystvami geologicheskoy sredy pri podzemnykh tekhnogennykh vozdeystviyakh. pod red. O. G. Latysheva [Theoretical bases of forecasting and management of properties of the geological environment upon underground anthropogenic influences. Edited by O. G. Latyshev]. Ekaterinburg, 216 p.

14. Walter Wittke. 2014, Rock Mechanics Based on an Anisotropic Jointed Rock Model (AJRM). Wilhelm Ernst \& Sohn. 865 p.

15. Sadovsky, M. A., Golubeva T. V., Pisarenko V. F., Schnierman M. G. 1984, Kharakternyye razmery gornoy porody i iyerarkhicheskiye svoystva seysmichnosti [Characteristic dimensions of rock and hierarchical properties of seismicity]. Izv. AN SSSR. Fizika Zemli [News of the USSR. Academy of Sciences. Physics of the Earth], no. 2, pp. 3-15.

16. Sadovsky M. A. 2004, Izbrannyye trudy: geofizika i fizika vzryva [Selected works: Geophysics and physics of explosion]. Moscow, 440 p.

17. Potapov A. A. 2005, Fraktaly v radiofizike i radiolokatsii: topologiya vyborki [Fractals in Radiophysics and radiolocation: topology of sample. Moscow, $848 \mathrm{p}$.

18. Sobol' I. M. 1978, Metod Monte-Karlo [The Monte-Carlo method]. Moscow, 64 p. 


\title{
Тренд-анализ свойств породного массива на основе фрактацьного представления пространственных рядов
}

\author{
Олег Георгиевич Латышев, \\ gtf.shs@ursmu.ru \\ Ольга Олеговна Казак \\ dozlat1@rambler.ru
}

\author{
Уральский государственный горный университет \\ Россия, Екатеринбург
}

\begin{abstract}
Оценка характеристик породного массива является основой проектирования технологии разработки месторождений полезных ископаемых, что свидетельствует об актуамьности работы.

Целью работы является установление закономерностей пространственного распределения свойств породного массива. Аия их установления требуется решение следуюших залач: определение вероятности наличия тренда; выявление и искююение выбросов (локальной состав^яюшей); построение минии тренда.

Методология исследований закАючается в использовании инструментария фррактальной геометрии м^я определения свойств случайного пространственного ряда. Применение аппарата классического тренд-анализа, основанного на чисто статистическом анализе, применительно к специсрике Аанных исследований не дает ацекватного решения указанных задач.

Результаты и их применение. В работе обсужАаются результаты реализации фрактамьного представления пространственных рядов на примере распределения прочности породного массива Юбилейного месторождения (Башкортостан). Количественная оценка линии тренда как фрактального объекта закиючается в определении ее фрактальной размерности методом "фрактальных миин". Пошаговая реализация метода позволила выявить участки породного массива с закономерной изменчивостью свойств по глубине. Вариация значений ряда (случайная составляюшая) подчиняется уравнению фрактаиьного броуновского Авижения (ФБА). Определение параметров этого уравнения Аает возможность прогнозировать характеристики породного массива на тех участках, гле инженерно-геологического опробования не проводилось. Аия этого разработана статистическая модель изменчивости характеристик массива, основанная на методе Монте-Карло. Реализация модели позволяет Аополнять пространственные ряды (тиражировать выборку), т. е. прогнозировать свойства массива между точками опробования.

Выводы. Совокупность премложенных методов и компьютерных программ формирует методику фрактального анализа изменчивости характеристик породного массива по глубине и простиранию месторождения. Методика дает дополнительную инсормацию при инженерногеологических исследования месторождений, особенно при ограниченном объеме выборочных Аанных, и позволяет повысить нацежность прогноза горнотехнических условий строительства шахт и добычи полезных ископаемых.
\end{abstract}

Киючевые слова: горные породы; прочность породного массива; фрактачьный тренд-анамиз.

\section{ЛИТЕРАТУРА}

1. Латышев О. Г., Казак О. О. Математические методы в горном деле. Екатеринбург: Изд-во УГгУ, 2013. 146 с.

2. Contreras L.F., Edwin T., Brown M. Bayesian data analysis to quantify the uncertainty of intact rock strength // Journal of Rock Mechanics and Geotechnical Engineering. 2018. No 10. pp. 11-31.

3. Hoek E, Brown E. T. Practical estimates of rock mass strength // International Journal of Rock Mechanics and Mining Sciences. 1997. No. 34 (8). pp. 1165-1186.

4. Miranda T., Sousa L. R., Gomes A. T., Tinoco J., C. Ferreira C. Geomechanical characterization of volcanic rocks using empirical systems and data mining techniques // Journal of Rock Mechanics and Geotechnical Engineering. 2018. No. 10. pp. 138-150.

5. Khani A., Baghbanan A., Norouzi S., Hashemolhosseini H. Effects of fracture geometry and stress on the strength of a fractured rock mass // International Journal of Rock Mechanics \& Mining Sciences. 2013. No. 60. pp. 345-352.

6. Латышев О. Г., Карасев К. А., Мартюшов К. С. Фрактальный тренд-анализ изменчивости временных и пространственных рядов свойств горных пород и массивов // Изв. вузов. Горный журнал. 2013. № 2. С. 73-79.

7. Мартюшов К. С. Прогноз прочности породного массива // Изв. вузов. Горный журнал. 2013. № 1. С. 44-47.

8. Кобзарь А. И. Прикладная математическая статистика: для инженеров и научных работников. М.: Физматлит, 2006.816 с.

9. Мандельброт Б. Фрактальная геометрия природы: пер. с нем. М.: Изд-во ИКИ, 2002. 656 с.

10. Федер Е. Фракталы: пер. с англ. М.: Мир, 1991. 262 с.

11. Крылов С. С., Бобков Н. Ю. Фракталы в геофизике. СПб.: Изд-во СПбГУ, 2004. 138 с.

12. Кроновер Р. Фракталы и хаос в динамических системах: пер. с англ. М.: Техносфрера, 2006. 488 с.

13. Теоретические основы прогноза и управления свойствами геологической среды при подземных техногенных воздействиях / под ред.

О. Г. Латышева. Екатеринбург: Изд-во УГГУ, 2007. 216 с.

14. Wittke W. Rock Mechanics Based on an Anisotropic Jointed Rock Model (AJRM). Wilhelm Ernst \& Sohn. 2014. 865 p.

15. Садовский М. А., Голубева Т. В., Писаренко В. Ф., Шнирман М. Г. Характерные размеры горной породы и иерархические свойства сейсмичности // Изв. АН СССР. Физика Земли. 1984. № 2. С. 3-15.

16. Садовский М. А. Избранные труды: геофизика и физика взрыва. М.: Наука, 2004. 440 с.

17. Потапов А. А. Фракталы в радиофизике и радиолокации: топология выборки. М.: Университетская книга, 2005. 848 с.

18. Соболь И. М. Метод Монте-Карло. М.: Наука, 1978. 64 с. 